\title{
IN VITRO PROPAGATION FOR PEACH ROOTSTOCK (NEMAGUARD)
}

\author{
Abd Alhady, Mohamed Reda A. \\ Tissue Culture Unit, Department of Genetic Resources, Desert \\ Research Center, El-Matareya, Cairo, Egypt \\ E-mail: mohamedreda240@yahoo.com
}

A $\begin{aligned} & \text { procedure for micropropagation of Nemaguard peach } \\ & \text { rootstock was developed using stem nodal segments as } \\ & \text { explants for in vitro establishment. Hundred percent of }\end{aligned}$ explants survived with high proliferation of shoots, growth percentage to survival and average shoot length was obtained on Murashige and Skoog (MS) basal medium supplemented with a combination of 0.5 $\mathrm{mg} / \mathrm{L}$ 6-benzyl amino purine (BAP) plus $0.2 \mathrm{mg} / \mathrm{L}$ indole acetic acid (IAA). The maximum number of proliferated shoots (7.0 shoots/explant) was obtained on MS medium supplemented with 3.0 $\mathrm{mg} / \mathrm{L}$ BAP $+0.5 \mathrm{mg} / \mathrm{L}$ 2-isopentenyladene (2iP). Meanwhile, MS basal medium without growth regulators induced the highest shoot length compared with other treatments. However, shoot elongation decreased with the increase of BAP concentration. Ninety percent of the shoots rooted on MS medium supplemented with $3.0 \mathrm{mg} / \mathrm{L}$ indole butyric acid (IBA) to obtain complete plants with the maximum average root number/shoot (5.8). On the other hand, the maximum root length $(8.5$ and $7.2 \mathrm{~cm})$ was obtained when IBA or naphthalene acetic acid (NAA) were supplemented to half strength MS media at $3.0 \mathrm{mg} / \mathrm{L}$. High survival, over $90 \%$, was obtained when the plantlets were transferred to greenhouse conditions. The Nemaguard peach rootstock cans successfully micropropagated beginning with stem nodal segment without significant damage to mother plant. The in vitro Nemoguard peach rootstocks were planted in Saint Catherine, South Sinai, Egypt where chilling requirements for producing the rootstock seeds are available for commercial production. Hence, it is encouraged to grow Nemaguard peach rootstock under S. Catherine conditions for commercial seed production.

Keywords: Prunus persica, micropropagation, stem nodal segments, Saint Catherine

Peach tree is one of the most important deciduous fruit frees grown in Egypt, while the harvested area reached 33017 ha and produced 333487 tons (FAO, 2011). Peaches, Prunus persica L., which belong to the family Rotaceae, are originated in China and peach ranks second to apples among 
temperate zone deciduous fruit trees from the standpoint of production and value (Childers, 1978). A peach tree is highly demanded by Egyptian consumers. There are many peach varieties growing more widely now throughout the world. Peaches are native to China and their culture dates are back to at least 4000 years (Wang, 1985). The main problem with peach trees in Egypt is the declining of the orchard in a short time due to the infection of root system with root-knot nematodes. Rootstocks play major role in modern orchards. Recently, the importance of the rootstock is recognized and the grafted cultivar influence the vegetative and generative mass and the profitability of fruit production (Racsko et al., 2004). Moreover, the rootstock determines the ecological fitness of the tree. Their effects can be recognized in the health status of critical tree phonological stages, tree kilter and tree sensitivity to pests and diseases (Holb, 2002), moreover in the efficiency of pest and diseases management programs and fruit yield (Holb et al., 2003). Nemguard peach (Prunus persical X Prunus davidiana Carrere) is used extensively as rootstock for peach cultivars; which is a vigorous grower and extremely disease resistant, proven resistance to root-knot nematodes, more resistant to crown gall than other rootstocks and widely used and preferred for peaches, almonds and plums.

Propagation of Nemaguard by hardwood or softwood cuttings is considering a problem (Alsalihy et al., 2004). Moreover, occurrence of the undesired segregation usually associated with the sexual propagation by seeds was also hoped to be entirely avoided. Seeds have double dormancy (external and internal dormancy). External dormancy occurs when a hard, impervious seed coat acts as a barrier to water, oxygen, and the exchange of other gases or when seed coat contains chemical inhibitors; meanwhile in internal dormancy occurs when internal conditions within the seed itself act as a barrier to germination by inhibitors (phenolics and abscisic acid). So, the seeds need different pre-germination treatments to germination as endocarp removal, stratification and gibberellic acid treatment (Davies and Duray, 2011). All nurseries use the covenantal propagation of Nemaguard by seeds, because of difficult root formation of cutting. Since there are considerable cross pollination in peach, the resulted rootstocks are not uniformity and it affect the characteristics of cultivars, which be grafted on it. So, vegetative propagation of rootstocks is a critical issue in order to replace seedling rootstocks and avoid its bad effects on produced cultivars. There are outstanding efforts made to improve rootstock root ability (Farmer and Besemann, 1974 and Robitaille and $\mathrm{Yu}, 1980$ ) but these systems have proved to be not useful enough to become standard propagation methods, especially because its production is limited by the available number of stock plant. So, establishment of a protocol for micropropagation is very important. Whereas micropropagation by using microshoots from 
Nemaguard peach mother tree as explants is a true to type propagation and most often associated with mass production (Debergh and Read, 1991).

Finally, the technique presents several advantages and could offer serious opportunities for rapid mass propagation for healthy plant materials. Growth regulators are the most important influence factors in shoot regeneration (Bhojwani and Razdan, 1996). In Prunus sp., some growth regulators such as benzyl aminopurine (BAP), kinetin (Kin) and 2isopentenyladene (2iP) have been exploited for shoot regeneration (Mant et al., 1989). Adventitious shoot formation is being significantly affected by the type and concentration of the cytokinin used in regeneration media. Cytokinins comprise a separate class of growth substances and growth regulators. They produce various effects when applied to intact plants. They particularly stimulate protein synthesis and participate in cell cycle control. The effect of cytokinins is most noticeable in tissue cultures where they are used often together with auxins, to stimulate cell division and control morphogenesis. Added to shoot culture media, these compounds overcome apical dominance and release lateral buds from dormancy (Lindsey, 1997). Also, indole-butyric acid (IBA) and naphthalene acetic acid (NAA) could improve adventitious bud development in almond (Ainsley et al., 2001). To induce this process, growth regulators (cytokinins) are added to the culture medium in order to reduce apical dominance. For peach, the most frequently used growth regulators are BAP and kinetin, with concentrations varying from a minimum of $0.5-0.6 \mathrm{mg} / \mathrm{L}$ to a maximum of $1-1.2 \mathrm{mg} / \mathrm{L}$ in relation to the genotype and type of explant (Loreti et al., 1988). Since its chilling requirements are high and not available in Egypt, and needs millions of hard currency to import the seed basis. Therefore, the main goal of this study was to establish a micropropagation protocol for Nemaguard peach rootstocks in order to produce a large scale of plants in a short period of time.

\section{MATERIALS AND METHODS}

\section{Plant Materials}

Activity growing shoots of Nemaguard peach rootstock were collected as source of explants from seedlings grown in the greenhouse of the Tissue Culture Unit, Desert Research Center, El-Matareya, Cairo, Egypt. Stem nodal segments of about $1.5 \mathrm{~cm}$ in length were isolated from the shoots. The explants were washed in running tap water and then washed again thoroughly by adding few drops of tween 20 to remove the superficial dust particles as well as fungal and bacterial spores. They were then surface sterilized with $1.5 \%$ sodium hypochlorite solution for $20 \mathrm{~min}$ and rinsed three times with sterile double distilled water, then immersed in $250 \mathrm{mg} / \mathrm{L}$ 
mercuric chloride solution for 5 min and finally rinsed six times with sterile double distilled water inside the laminar air flow chamber.

\section{Nutrient Medium and Culture Conditions}

The basal nutrient medium containing macro and microelements applied throughout this study was Murashige and Skoog (MS) medium (Murashige and Skoog, 1962) supplemented with $100 \mathrm{mg} / \mathrm{L}$ myo-inositol, 30 $\mathrm{g} / \mathrm{L}$ sucrose, $2 \mathrm{~g} / \mathrm{L}$ gelrite and $0.4 \mathrm{mg} / \mathrm{L}$ thiamine HCI. The $\mathrm{pH}$ value of the nutrient medium was adjusted at 5.7 to 5-8 with adding few drops of either $0.1 \mathrm{~N} \mathrm{NaOH}$ or $0.1 \mathrm{~N} \mathrm{HCI}$, prior to the addition of gelrite. The media were dispensed into jars, each contained $50 \mathrm{ml}$ of culture medium. Sterilization of the medium was achieved by autoclaving the jars containing media under pressure of $1.1 \mathrm{~kg} / \mathrm{cm}^{2}$ and at $120^{\circ} \mathrm{C}$ for $20 \mathrm{~min}$. Four explants were inoculated aseptically into the culture medium and placed in each jar, then incubated in a growth chamber at $25^{\circ} \mathrm{C}$ for 16 -h/day photoperiod using cool white fluorescent lamps (3000 lux).

\section{Establishment Stage}

Shoot tips were inoculated on MS medium supplemented with different concentrations of BAP $(0.0,0.1,0.5$ and $1.0 \mathrm{mg} / \mathrm{L})$ either individually or in combination with indol acetic acid (IAA; 0.0, 0.1, and 0.2 $\mathrm{mg} / \mathrm{L}$ ). Survival percentage, growth percentage to survival and average shoot length were evaluated after six weeks from culture on the establishment medium.

\section{Multiplication Stage}

Shoots obtained from the establishment stage were transferred to jars containing MS basal medium supplemented with BAP at concentrations of $0.00 .5,1.0,2.0,3.0$ and $4.0 \mathrm{mg} / \mathrm{L}$ and $2 \mathrm{iP}$ at concentration of $0.5 \mathrm{mg} / \mathrm{L}$. Shoot proliferation was determined after six weeks of culture. Average number of new shoots formed per explant and average shoot length $(\mathrm{cm})$ were recorded.

\section{Induction of Rooting and Acclimatization}

For rooting, individual shoots $3-4 \mathrm{~cm}$ long were excised from the multiplication stage and cultured on half strength MS basal medium supplemented with IBA or NAA, each at concentrations of $0.0,1.0,2.0$ and $3.0 \mathrm{mg} / \mathrm{L}$. The percentage of rooted shoots, average number of roots formed per shoot and average root length $(\mathrm{cm})$ were determined after six weeks of culture on the rooting media. Rooted shoots were removed from the culture medium and the roots were washed in sterile distilled water. The plantlets were then transferred to plastic pots containing peat moss and sand (1:1) in greenhouse $\left(28 \pm 2^{\circ} \mathrm{C}, 70 \%\right.$ relative humidity). The potted plants were irrigated and initially covered with plastic bags, which were gradually 
eliminated within eight weeks for completing their acclimatization and plantlets were maintained under nursery conditions. The acclimatized plantlets were transferred to be cultured under Saint Catherine conditions.

\section{Experimental Design and Statistical Analysis of Data}

Experiments were subjected to a completely randomized design. Analysis of variance (ANOVA) and Duncan's multiple range test (Duncan, 1955), as modified by Snedecor and Cochran (1998), were used to analyze the obtained data. Each experiment included at least 20 replicates and was repeated twice. The differences among mean values were estimated for significance at $5 \%$ level. The means followed by the same letter are not significantly different at $P \leq 0.05$.

\section{RESULTS AND DISCUSSION}

\section{Establishment Stage}

From data represented in table (1), it could be noticed that survival percentage of Nemaguard culture, using different concentrations of BAP and IAA including the control (without plant growth regulators), ranged from 70 to 100 percent. Growth percentage ranged between 57 and $100 \%$. However the combination of BAP and IAA at a concentration of 0.5 and $0.2 \mathrm{mg} / \mathrm{L}$, respectively was the best treatment, since both the survival and growth percentages attained $100 \%$. The highest average length of shoot $(4.6 \mathrm{~cm})$ was obtained also on the same medium and it decreased gradually with the increase in BAP concentration (Fig. 1a). The control medium gave a higher average shoot length $(4.3 \mathrm{~cm})$ comparing to the media supplemented with $0.1 \mathrm{mg} / \mathrm{L}$ IAA with different concentrations of BAP.

Table (1). Effect of BAP and IAA on the in vitro establishment of Nemaguard peach rootstock after six weeks of culhre on MS medium.

\begin{tabular}{|c|c|c|c|c|}
\hline \multicolumn{2}{|c|}{ Treatments $(\mathrm{mg} / \mathrm{L})$} & \multirow{2}{*}{ Survival (\%) } & \multirow{2}{*}{$\begin{array}{c}\text { Growth }(\%) \\
\text { to survival }\end{array}$} & \multirow{2}{*}{$\begin{array}{c}\text { Average } \\
\text { shoot length } \\
\text { (cm) }\end{array}$} \\
\hline BAP & IAA & & & \\
\hline 0.0 & 0.0 & 70 & 57 & $4.3 b$ \\
\hline 0.1 & 0.1 & 90 & 78 & $4.0 \mathrm{c}$ \\
\hline 0.5 & 0.1 & 80 & 100 & $3.4 \mathrm{c}$ \\
\hline 1.0 & 0.1 & 80 & 88 & $3.1 \mathrm{~d}$ \\
\hline 0.1 & 0.2 & 90 & 89 & $4.5 \mathrm{a}$ \\
\hline 0.5 & 0.2 & 100 & 100 & $4.6 \mathrm{a}$ \\
\hline 1.0 & 0.2 & 80 & 88 & $4.2 \mathrm{~b}$ \\
\hline
\end{tabular}

The general trend of responses of shoot growth to different auxin concentrations in the media may be interpreted by the fact that the auxin 
affects mainly the length of shoots and not through any other mechanism. On the other hand, the effect of auxin on morphogenetic responses of shoots varied relatively according to concentrations of cytokinin in the media. The results are in agreement with theses of Mahdavian et al. (2011) and Edriss et al. (2014), who reported that maximum shoot length of cherry and Nemaguard rootstocks were achieved when culturing on MS medium supplemented with $0.5 \mathrm{mg} / \mathrm{L}$ of BAP followed by those cultured on $1.0 \mathrm{mg} / \mathrm{L}$ BAP.

\section{Multiplication Stage}

Effect of various combinations of BAP and $2 \mathrm{iP}$ on the multiplication of shoots is presented in table (2). The cytokinin free medium gave the least average number of shoots indicating strong apical dominance. BAP and $2 \mathrm{iP}$ stimulated the production of maxillary shoots regardless of their concentration. BAP and $2 \mathrm{iP}$ at concentrations of $3.0 \mathrm{mg} / \mathrm{L}$ and $0.5 \mathrm{mg} / \mathrm{L}$, respectively, induced significantly the maximum shoots number $(7$ shoots/ explant) than did other treatments (Fig. 1b). The results are in agreement with those of Soliman (2013), who found that maximum number of peach shoots were obtained on Woody Plant medium containing $2 \mathrm{mg} / \mathrm{L} \mathrm{BAP}$ and $0.5 \mathrm{mg} / \mathrm{L} 2 \mathrm{iP}$. The increases in shoot proliferation may be due to the effect of cytokinin, especially when added in appropriate concentration, where it regulates shoot proliferation, cell division and differentiation (Gross and Partiner, 1994). On MS medium without cytokinins (control), an average of 2.0 shoots per explant were recorded after six weeks of culture with the highest average shoot length $(4.4 \mathrm{~cm})$. It seems that BAP and 2iP could stimulate shoot growth if added to the media at low concentrations, while their high concentrations stimulate shoot multiplication.

Table (2). Effect of $\mathrm{BAP}$ and $2 \mathrm{iP}$ on in vitro shoot multiplication of Nemaguard peach rootstock after six weeks of culture on MS medium.

\begin{tabular}{cccc}
\hline \multicolumn{2}{c}{ Treatments $(\mathbf{m g} / \mathbf{L})$} & $\begin{array}{c}\text { Average no. of } \\
\text { shoots/explant }\end{array}$ & $\begin{array}{c}\text { Average shoot } \\
\text { length }(\mathbf{c m})\end{array}$ \\
\cline { 1 - 2 } BAP & $\mathbf{2 i P}$ & $2.0 \mathrm{e}$ & $4.4 \mathrm{a}$ \\
0.0 & 0.0 & $5.6 \mathrm{~d}$ & $3.5 \mathrm{~b}$ \\
0.5 & 0.5 & $5.6 \mathrm{~d}$ & $3.1 \mathrm{c}$ \\
1.0 & 0.5 & $6.5 \mathrm{c}$ & $2.7 \mathrm{~d}$ \\
2.0 & 0.5 & $7.0 \mathrm{a}$ & $2.5 \mathrm{e}$ \\
3.0 & 0.5 & $6.8 \mathrm{~b}$ & $2.4 \mathrm{e}$ \\
4.0 & 0.5 & & \\
\hline
\end{tabular}

The results indicate that BAP plays a key role in shoot propagation of Nemagaurd peach rootstock. This cytokinin is an efficient growth 
regulator for shoot multiplication in other plants, such as Centaurea pauilossos (Cueneca et al., 1999), Centaurea junoniana (Hammat and Evans, 1985), Solenostemma argle (Abd Alhady, 2011), Amygdalus communs (Sharifinoghaddam et al., 2011) and Nemaguard, okinawa peach rootstocks (Edriss et al., 2014) and Volkamer lemon (Ahmed et al., 2017). For Nemaguard peach rootstock, BAP proved to be the most effective cytokinin for shoot multiplication but not for shoot elongation (Table 2). The increase in number of shoots of Nemaguared peach rootstock may be due to the physiological role of BAP, which is thus to break the apical dominance and stimulate growth of new shoots (Pruski et al., 2005). Shoot elongation decreased slightly with increasing BAP concentration. This result suggests an inverse relationship between the number of shoots and shoot elongation. The reduced shoot elongation was observed in other propagation protocols (Ault, 1994 and Cueneca et al., 1999).

\section{Induction of Rooting and Acclimatization}

About 3-4 cm long shoots with 3-4 leaves, harvested from in vitro proliferated shoots, were placed in half strength MS medium supplemented with different concentrations of IBA or NAA $(0.0,1.0,2.0$ and $3 \mathrm{mg} / \mathrm{L})$. The shoots showed different responses to rooting after six weeks of culture (Table 3). The highest percentage of rooting $(90 \%)$ was obtained on half strength MS medium supplemented with $3.0 \mathrm{mg} / \mathrm{L}$ IBA (Fig. 1c). On the other hand, in case of NAA, the highest rooting percentage of Nemguard peach rootstock shoots $(70 \%)$ was obtained at a concentration of $3.0 \mathrm{mg} / \mathrm{L}$ NAA. As shown in table (3), no rooting percentage was obtained on half strength MS medium without auxin. This result is in harmony with that obtained by Durkovic (2008). Also, Komalavalli and Rao (1997 and 2000) noticed that from the three auxins; IAA, IBA and NAA tested to induce rooting of Gymnema sylvestre, IBA ( $3 \mathrm{mg} / \mathrm{L}$ ) was the most effective for root induction and survival in the field. The maximum number of root/shoot was also obtained when IBA were added to half strength MS medium at concentration of $3.0 \mathrm{mg} / \mathrm{L}$. On the other hand, the maximum root length $(8.5$ and $7.2 \mathrm{~cm}$ ) was obtained when IBA or NAA were supplemented to half strength MS medium at $3.0 \mathrm{mg} / \mathrm{L}$. 
Table (3). Effect of IBA and NAA on the in vitro rooting of Nemaguard peach rootstock after six weeks of culture on $1 / 2$ MS medium.

\begin{tabular}{|c|c|c|c|c|}
\hline \multicolumn{2}{|c|}{ Treatments $(\mathrm{mg} / \mathrm{L})$} & \multirow{2}{*}{$\begin{array}{c}\text { Rooting } \\
\text { percentage } \\
(\%)\end{array}$} & \multirow{2}{*}{$\begin{array}{c}\text { Average } \\
\text { roots/shoot }\end{array}$} & \multirow{2}{*}{$\begin{array}{c}\text { Average } \\
\text { root lengtl } \\
\text { (cm) }\end{array}$} \\
\hline IBA & NAA & & & \\
\hline 0.0 & 0.0 & 0 & 0.0 & 0.0 \\
\hline 1.0 & 0.0 & 70 & $2.5 \mathrm{~d}$ & $5.5 \mathrm{e}$ \\
\hline 2.0 & 0.0 & 80 & $3.7 b$ & $7.0 \mathrm{c}$ \\
\hline 3.0 & 0.0 & 90 & $5.8 \mathrm{a}$ & $8.5 \mathrm{a}$ \\
\hline 0.0 & 1.0 & 50 & $1.5 \mathrm{f}$ & $4.5 \mathrm{f}$ \\
\hline 0.0 & 2.0 & 60 & $2.0 \mathrm{e}$ & $6.5 \mathrm{~d}$ \\
\hline 0.0 & 3.0 & 70 & $3.5 c$ & $7.2 \mathrm{~b}$ \\
\hline
\end{tabular}
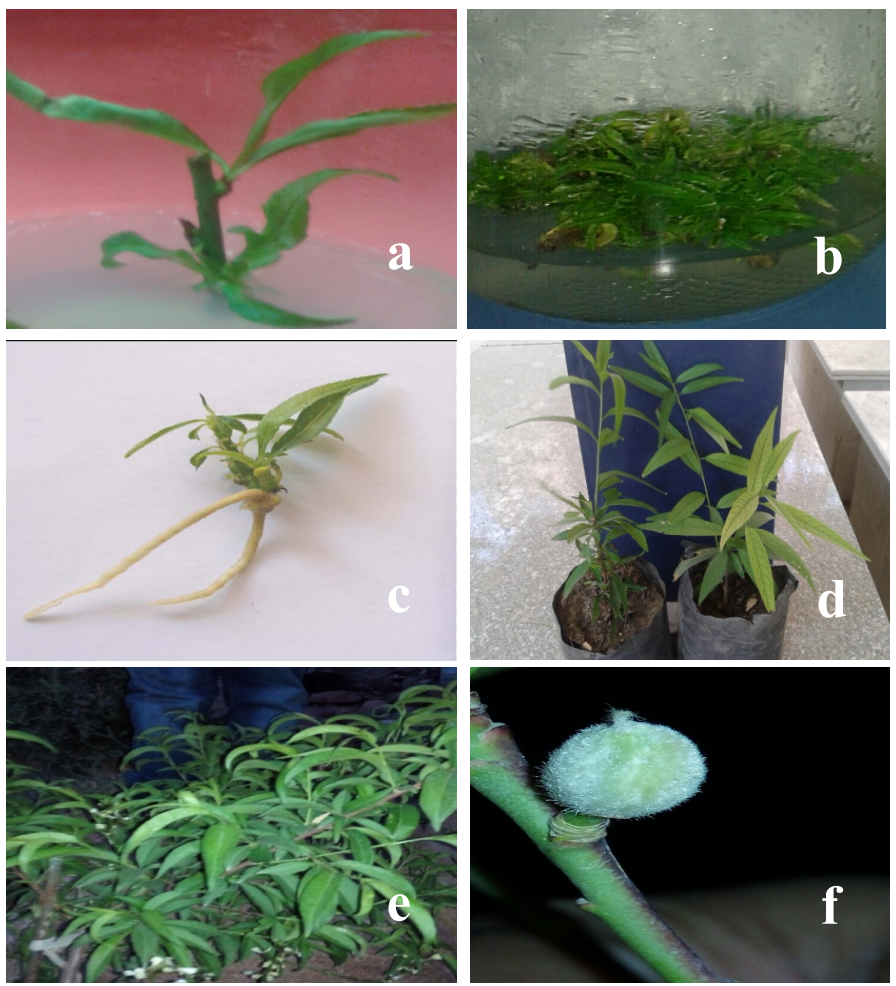

Fig. (1). In vitro propagation of Nemagard Peach rootstock; (a) establishment of Nemagard Peach rootstock, (b) multiplication of shoots, (c) in vitro rooted plantlet after six weeks of culture, (d) plantlets acclimatized in greenhouse, (e) in vitro Nemagard Peach rootstock planted under saint Catherine conditions and (f) plants producing seeds.

Egyptian Res., J. Desert 68, No. 1, 1-13 (2018) 
Endogenous hormones might have a role in promoting plants to root. Until the hormonal balance reached its optimal level to push the roots to grow and develop in the presence of exogenous hormones, since increasing auxin concentration promotes root formation on shoot bases (George and Shermington, 1984). The use of half-strength MS medium for root induction of Nemaguared peach rootstock was supported by Beena et al. (2003), who reported that half-strength MS medium induced more roots compared to fullstrength MS in Ceropegia candelabrum. In the root meristem, auxin is implicated in regulating the pattern of cell division and differentiation (Friml, 2003). According to Puente and Martin (1997); if the shoots are competent to root, rooting rate could be increased easily. It has been reported that shoot characteristics sent as size and shoot culture origin fall to attain a stabilized growth phase or apparent rejuvenation can also lead to a variable rooting response (Marks and Simpson, 2000). The beneficial effect of IBA on rooting has been observed in many plant species (Linh, 2001; Amri et al., 2010; Cheniany et al., 2010 and Ahmed et al., 2017). Lack of rooting morphogenesis may be due to lack of cell sensitivity to respond to morphogenesis (Hartmann et al., 1997). Similarly, auxins are involved in the process of adventitious root formation in many woody plants; IBA is commonly used to promote root initiation.

Plantlets with well-developed root system were transferred to plastic pots covered with translucent plastic bags to ensure high humidity around the plants. The use of this procedure during the acclimatization phase ensured that most plantlets transplanted to ex vitro conditions continued growing vigorously. After six weeks and when the plastic bags were removed, $90 \%$ of the plantlets survived in the greenhouse and showed no sign of water stress (Fig. 1d). Thereafter, the regenerated plants showed normal growth. The in vitro Nemoguard peach rootstocks were planted in Saint Catherine, South Sinai, Egypt where chilling requirements for producing the rootstock seeds are available for commercial production (Fig. le and f). Hence, it is encouraged to grow Nemaguard peach rootstock under Saint Catherine conditions for commercial seed production.

\section{REFERENCES}

Abd Alhady, M.R. (2011). Propagation of Solenostemma arghel (Dcl) Hayne in vitro. American Eurasian J. Agric. Environ. Sci., 11 (6): 771-775.

Ahmed, M.E.E., A. Abido, M.A. Aly, M.M. Abdulla and R.E.E. Abo ElFadl (2017). In vitro propagation of Volkamer lemon using nodal cutting segments. J. Adv. Agric. Res., Faculty of Agriculture, Saba Basha, Alexandria, 22 (3): 498. 
Ainsley, P.J., F.A. Hammerschlag, T. Bertozzi, G.G. Collins and M. Sedgley (2001). Regeneration of almond from immature seed cotyledons. Plant Cell, Tissue and Organ Culture, 67: 21-226.

Alsalihy, A.W., B. Krizan, M. Klems, H. Fiserova and J. Hradilk (2004). The effect of growth regulators on the rooting of shoots of the peach rootstock Ishtara in in vitro conditions. Hortscince, 31 (4): 124-131.

Amri. E., H.V.M. Lyaruu, A.S. Nyomora and Z.L. Kanyeka (2010). Vegetative propagation of African Blackwood (Dalbergia melanoxylon Guill. \& Perr.): effects of age of donor plant, IBA treatment and cutting position on rooting ability of stem cuttings. New Forests, 39: 183-194.

Ault, J.R. (1994). In vitro propagation of Eriostemon myoporoids and Eriostemon "stardust". HortSci., 29: 686-688.

Beena, M.R., K.P. Martin, P.B. Kirti and H. Molly (2003). Rapid in vitro propagation of medicinally important Ceropegia candelabrum. Plant Cell, Tissue and Organ Culture, 72: 285-289.

Bhojwani, S.S. and M.K. Razdan (1996). In "Plant Tissue Culture: Theory and Practice". Studies in Plant Science Vol. 5.

Cheniany, M., H. Ebrahimzadeh, A. Masoudi-nejad, K. Vahdati and C. Leslie (2010). Effect of endogenous phenols and some antioxidant enzyme activities on rooting of Persian walnut (Juglans regia L). African Journal of Plant Science, 4 (12): 479-487.

Childers, N.F. (1978). In "Modern Fruit Science", $8^{\text {th }}$ edition. Horticulture Publication Rutgers University, the State University, New Brunswick, New Jersey, 08903 USA.

Cueneca, S., J.B. Amo-Marco and R. Parra (1999). Micropropagation from inflorescence stem of the Spanish endemic plant Cenaurea pauiloscosexwllk (Compositae). Plant Cell Rep., 18: 674-679.

Davies, F.T.Jr. and S.A. Duray (2011). In "Laboratory Exercises in Plant Propagation", $14^{\text {th }}$ ed. Copy Corner, College Station, T.X.

Debergh, P.C. and P.E. Read (1991). In "Micropropagation". (Debergh, P.C. and R.H. Zimmerman Eds.). Micropropagation Technology and Application. Kluwer Academic Pulishers, Dordrecht, p. 1-13.

Duncan, D.B. (1955). Multiple range and multiple f tests. Biometrics, 11: 142.

Durkovic, J. (2008). Micropropagation of mature Corns mas 'Macrocarpa'. Trees, 22: 597-602.

Edriss, M.H., G.A. Baghdadi, A.M. Abd El-Razek, G.A. Abdrabboh, and H.F. Abdel-Aziz (2014). Micropropagation of some peach rootstocks. Nature and Science, 12 (3): 106-114.

FAO (2011). The world Bank, WTO, IFPR and the UN HLTF Price volatility in food and agricultural markets policy responses. 
Farmer, R.E.Jr. and K.D. Besemann (1974). Rooting cutting from physiologically mature black cherry. Silvae Genet., 23: 99-134.

Friml, J. (2003). In "Auxin Transport-Shaping the Plant". (Friml, J. Ed.). Current Opinion in Plant Biology, Elsevier Science Ltd., Berlin, Germany, p. 7-12.

George, E.F. and P.D. Shermington (1984). In "Plant Propagation by Tissue Culture". $3^{\text {rd }}$ Ed. Springer.

Gross, D. and B. Partiner (1994). Novel natural substances acting in plant growth regulation. Journal of plant Growth Regulation, 13 (2): 93114.

Hammat, N. and P.K. Evans (1985).The in viro propagation of an endangered species Centaurea Junoniana Savant. (Composite). J. HortSct., 60: 93-97.

Hartmann, H.T., D.E. Kester, F.T. Davies and R.L. Genever (1997). In "Plant Propagation Principle and Practices". $6^{\text {th }}$ ed. Prentice Hall of India Private Limited, New Delhi.

Holb, I.J. (2002). In "Epidemiological Characteristics of the Disease. Apple Scab: Biology, Forecasting and Control. (Holb, I. Ed.). Szaktudas Kiado Haz Press, Budapest, p. $29-55$.

Holb, I.J., B. Heijn and M. J. Jeger (2003). Sumer epidemics of apple scab: the relationship between measurements and their implications for the development of predictive models and threshold levels under different disease control regimes. Journal of Physiopathology, 151 (6): 335-343.

Komalavalli, N. and M.V. Rao (1997). In vitro micropropagation of Gymnema elegans W\& A, a rare medicinal plant. Indian Journal of Experimental Biology, 35: 1088-1092.

Komalavalli, N. and M.V. Rao (2000). In vitro micropropagation of Gymnema sylvestre - A multipurpose medicinal plant. Plant Cell, Tissue and Organ Culture, 61: 97-105.

Lindsey, K. (1997). In "Plant Tissue Culture Manual". Available online: link.springer.com/book

Linh, Le C. (2001). Factors influencing in vitro rooting of chestnut. Forest Snow Landscape Research, 3 (18): 468-470.

Loreti, F., S. Morini and S. Concetti (1988). Effect of potassium and nitrogen concentration on growth of peach shoots cultured in vitro. Acta Horticulturae, 227 (19): 311-317.

Mahdavian, M., N. Bouzari and H. Abdollah (2011). Effects of media and plant growth regulators on micropropagation of a dwarfing cherry rootstock. (PHL-A). Biharean Biologist, 5 (2): 86-90. 
Mant, S., R.S. Ccorza and J.C. Ordts (1989). Plant regeneration from cotyledons of Prunus persica, Prunus domestica and Prunus ceraasus. Plant Cell, Tissue and Organ Culture, 19: 1-11.

Marks, T.R. and S.E. Simpson (2000). Rhizogenesis in forsythia x intermedia and Syringa vulgaris. Application of simple internode experimental system. Plant Cell Reports, 19: 1171-1176.

Murashige, T. and F.A. Skoog (1962). A revised medium for rapid growth and bioassays with tobacco tissue cultures. Physiological Plantarum, 15: 473-479.

Pruski, K., T. Astatkie and J. Nowak (2005). Tissue culture propagation of Mongolian cherry (Prunus froticosa) and Nanking cherry $(P$. tomentosa). Plant Cell, Tissue and Organ Culture, 82: 207-211.

Puente, J. and J.A. Martin (1997). In vitro root ability of colonel apple micro cuttings derived from rooted and unrooted shoots. Scientia Horticulturae, 68: 227-230.

Racsko, J., J. Z. Nyki, Szab, M. Soltesz and E. Farkas (2004). Effect of rootstocks on blooming capacity and productivity of apple cultivars. J. Agric. Sci., 15: 14-20.

Robitaille, H.A. and K.S. Yu (1981). Rapid multiplication of peach clones from sprouted nodal cutting. Hortscience, 15: 579-580.

Sharifmoghaddam, N., A.S. Jad and S. Mohammad (2011). The Effect of plant growth regulators on callus induction and regeneration of Amygdalus communis. Notulae Scientia Biological, 3 (3): 97-100.

Snedecor, G.W. and G.W. Cochran (1980). In "Statistical Methods". 6 ed. Iowa Univ. Press Iowa. USA.

Soliman, H. (2013). In vitro regeneration and genetic transformation of peach (Prunus persica) plants. Life Science Journal, 10 (2): 487 -496.

Wang, Y. (1985). Peach growing and germplasm in China. Acta Hort., 173: $51-55$.

Egyptian Res., J. Desert 68, No. 1, 1-13 (2018) 


\section{الإكثار المعملي لأصل الخوخ (نيما جارد)}

محمد رضا عبد المجيد عبد الهادي

وحدة زراعة الأنسجة، قسم الأصولّ الور اثثة، مركز بحوث الصحر اء، المطرية، القاهرة،

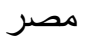

أجريت هذه الدراسة للإكثار الدقيق لأصل الخوخ النيماجارد، حيث أستخدمت الأجزاء

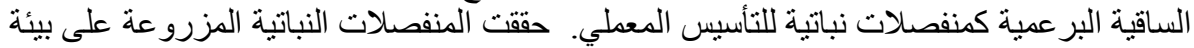

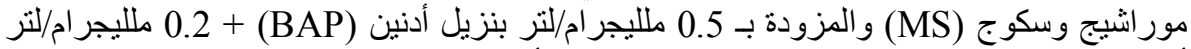

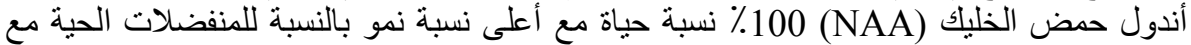

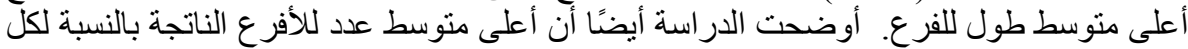

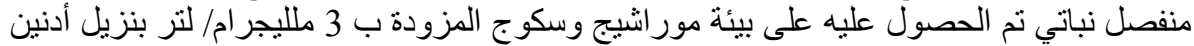

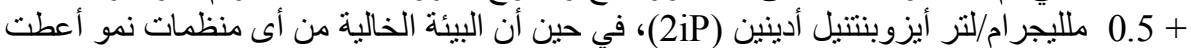

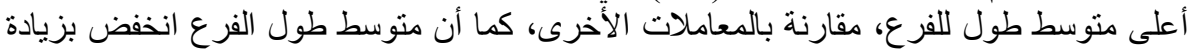

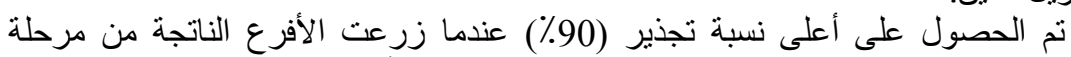

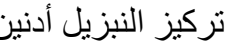

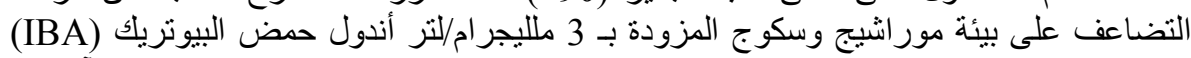

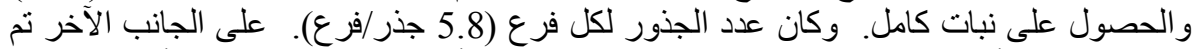

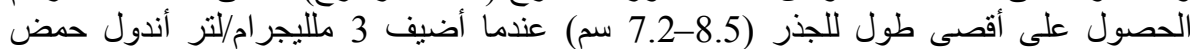

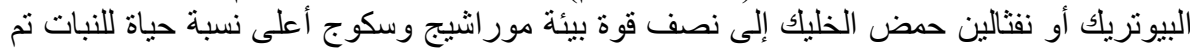

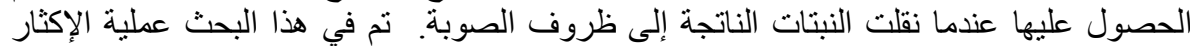

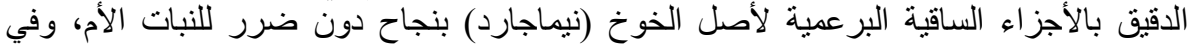

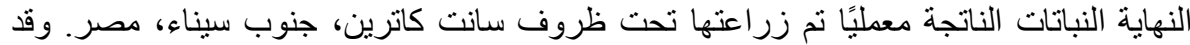

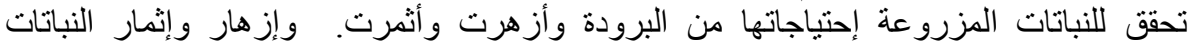

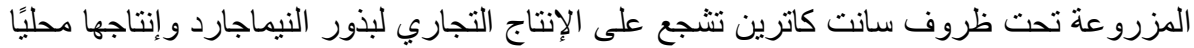

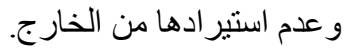

